\title{
Perfect Geopolitics and Strategies to Maintain Russia as a World Power
}

\author{
Luca Diaconescu, Mirela Elena Mazilu \\ Doctoral School of Sciences, University of Craiova, Field of Geography, Craiova, Romania \\ Email address: \\ diaconesculuca@yahoo.ro (L. Diaconescu),mirelamazilu2004@yahoo.com (M. E. Mazilu)
}

\section{To cite this article:}

Luca Diaconescu, Mirela Elena Mazilu. Perfect Geopolitics and Strategies to Maintain Russia as a World Power. Journal of Public Policy and Administration. Vol. 5, No. 2, 2021, pp. 37-43. doi: 10.11648/j.jppa.20210502.12

Received: March 24, 2021; Accepted: April 14, 2021; Published: May 8, 2021

\begin{abstract}
Russia has been on the international stage as a superpower of 10 centuries, reaching its peak in the second half of the twentieth century, when under the leadership of the U.S.S.R. dominated the socialist world, owning the northern half of Asia and the eastern half of Europe, when it had twice the surface area of any other state on Earth, being as much as the USA, China and India together. Even after the most spectacular growth, it experienced its greatest decline, the current Eurasian power and center of Orthodox civilization being in a severe demographic decline, increasingly disadvantaged compared to its highly populated neighbors and in a space crisis and being in the vicinity of the second great dismemberment after the one in 1991, risking its decline to critical dimensions, which would turn it into a small retrograde power, representing the definition of geopolitical failure and probably becoming a shameful case study of this early 21 st century. However, there could be a set of perfect geopolitical decisions, which would prevent the national failure and the split of the country, avoiding a foreshadowed scenario for the current century, from which Russia could return among the world's powers, with vast natural, subsoil and agricultural resources so necessary to the booming economies of Asia or the growing population of Africa, giving the opportunity to this old people be respected and courted by all major importers of raw materials.
\end{abstract}

Keywords: Eurasia, USSR, Orthodox Civilization, Decline, Great Powers

\section{Introduction}

The orthodox civilization whose core state is Russia, reached its peak in the years 1960-1980, when the USSR dominated almost two thirds of Europe and Asia, reaching to influence states or territories that belong by right to the Western, Islamist or civilization worlds. Japanese, extending its decision-making power to America and Africa. Under his direct leadership were the Baltic states part of the Western world, Karelia, Islamist states in Central Asia, Mongolian and Turkish states in the provinces of Siberia and regions of Japanese civilization (Sakhalin Island and the Kurile Islands). But those times are over, the USSR losing in the years 19891990 the influence held in the states of Central Europe (East Germany, Czechoslovakia, Poland, Hungary, Romania, Yugoslavia, Bulgaria, Albania), Asia (China, Mongolia, Vietnam, Cambodia, Laos, South Yemen), Africa (Ethiopia, Angola, Mozambique) and America (Cuba, Bolivia, Nicaragua, Chile). Global influence was overwhelming, with a particular appeal in many other states including India, while the Commonwealth of Petroleum Exporting States was probably the largest anti-US movement and its allies, followed by a row of oil-rich states have become increasingly in control of exported oil prices, a movement that has led to regional powers or the most developed countries on the continents in which they are located (Venezuela, Kuwait, Saudi Arabia, Iran, Iraq, Libya, Algeria, Nigeria, United Arab Emirates United and so on). These states are now, with the withdrawal of the influence of the main ally, declining one by one under the pressure of authoritarian regimes, fluctuations in oil and gas prices and Western pressure to take revenge.

But the economic downturn that occurred after the 1980s not only caused the Russians to withdraw from world influence for the next two decades, but also to withdraw from the former socialist states that were part of the USSR, so in 1991, the second withdrawal of the Russian empire took place 16 states plus Russia, with a total of 6 in Europe (Belarus, Ukraine, Moldova, Estonia, Latvia, Lithuania), 3 Caucasian states (Armenia, Georgia, Azerbaijan) and 5 states 
in Asia (Kazakhstan, Uzbekistan, Turkmenistan, Tajikistan and Kyrgyzstan) [19, 20, 5]. Although Russia has recovered from the economic recovery, the lack of high-quality technology and the low price of resources and a rather unstable market for them have led to Russia with 17 million $\mathrm{km}^{2}$ and 144 million inhabitants be surpassed economically by states such as Canada with only 9.3 million $\mathrm{km}^{2}$ and 37 million inhabitants or South Korea with only 0.1 million $\mathrm{km}^{2}$ and 51 million inhabitants [21]. In a closer comparison with the small state of South Korea, Russia has a population three times larger and an area 170 times larger, very rich in resources and with access to three oceans, numerous seas and borders with 14 neighbors, while the state of South Korea has a territory similar to that of Hungary, Bulgaria or the Czech Republic, without subsoil resources and with a single land border with the state of North Korea, which is closed. Russia's Gross Domestic Product in the last 50 years, has surpassed South Korea's economy 45 times in 1970, 15 times in 1980, or 9 times in 1990, and in 2000 it will hold only $50 \%$ from the South Korean economy.

\section{Decline}

Russia and the 4 big problems:

1. the possibility of exporting raw materials and agriculture;

2. access to technology and investments with low risk of domination;

3. population decline in European Russia and Islamization from the south where there is a population explosion;

4. the low population of Asian Russia and the massive migration of the Chinese population from the neighboring mega-demographic center, at risk of territorial grabbing on the surface of the former Turkish-Mongol-Sino-Tibetan peoples, conquered by Russia in the last century.

Russia's current quarrels with Orthodox states in demographic decline and in the process of Islamic invasion are ominous for the interests of the entire Orthodox civilization. Instead, the population explosion in Islamist states poses serious problems for both Russia and the Christian Orthodox states around it, which easily brings an alliance between all these states, perhaps with residence outside Russia, such as in Bulgaria. Some of these countries, such as Romania, Bulgaria, Greece, Cyprus, Macedonia, the Republic of Moldova, Ukraine or Georgia, have higher hopes for the enlargement of the European Union to combat Islamization and see Russia as the second enemy.

The economic decline also endangers the Russian national spirit, even if it is constantly trying to revive it [18]. Although a number of actions considered nationalist are being resorted to, they are finding it increasingly difficult to cope with the wave of discontent and lethargy that Russia has entered. Anti-Western discourses, economic alliances with the European Union, China or Central Asia, military alliances with Turkey and Iran or both within the CIS, through economic pressures such as the natural gas crisis in the winter of 2009 or military interventions in Georgia since 2008, Ukraine between 2014 and the present and in Syria between 2015 and the present are just some of the measures aimed at raising the morale of a troubled nation.

The problem is becoming more and more acute, with serious pressure to start the third wave of imperial destructuring, so even people within the Russian Federation are nationalizing by seeking religious, cultural and economic models outside the Russian Orthodox world. [9]. Karelia tends to Catholicism-Protestants in the Western world (Finnish-German interests), Islamist peoples (Tatarstan, Bashkortostan, Dagestan, Chechnya, Ingushetia, KabardinoBalkaria, Karachay-Cherkessia) are experiencing a religious renaissance fraternizing with the southern Islamic states (Turkey, Saudi Arabia, Azerbaijan), Turkish-speaking provinces (most often Islamic) are increasingly attached to Turkey, Azerbaijan and Central Asian states (Yakutia, Altai, Tuva, Hakasija, Bashkortostan, Tatarstan, Chuvashia, Crimea, Dagestan, Cercasia and Kabardino-Balkaria) and Mongol peoples (Kalmykia, Buryatia, Altai, Tuva) lean towards a rapprochement with China, Japan and South Korea, the latter attracting in their sphere indigenous peoples, foreign to Russian civilization (the entire Uralic, Tungusic group or chukotko-kamchatkan) [3, 8, 13]. In the current situation, Russia is cornered and destructured even by its own allies such as Turkey or China, and the measures that need to be taken urgently are expected to be of the utmost care and wisdom, avoiding the continuation of economic or military pressures.

The area and population of the states with extra-Russian inclinations are: pro-Western European states: $170,000 \mathrm{~km}^{2}$ and 0.7 million inhabitants, pro-Islamist and pro-Turkish states: $1,600 \mathrm{~km}^{2}$ and 19.5 million inhabitants and states proeastern-Asians who include the whole of Siberia with an area of 13.1 million $\mathrm{km}^{2}$ and a population of 34 million. If Russia were to lose Siberia, from its current 17 million $\mathrm{km}^{2}$ area (over Canada, the USA, China or Brazil that follows it in the ranking, all with less than 10 million $\mathrm{km}^{2}$ ) and a population of 145 million inhabitants, would remain with only 4 million $\mathrm{km}^{2}$ and 110 million inhabitants, while if it were reduced to the 22 republics (holding 4.9 million $\mathrm{km}^{2}$ and 26 million inhabitants), 9 territories (have 4.7 million $\mathrm{km}^{2}$ and 21 million inhabitants), 4 autonomous districts (2.2 million $\mathrm{km}^{2}$ and 2 million inhabitants) and a Jewish territory (with 0.03 million $\mathrm{km}^{2}$ and 0.16 million inhabitants) area and population Russia would drop to 5.2 million $\mathrm{km}^{2}$ and 96 million inhabitants.

Thus, the total area of the USSR, which was 22.5 million $\mathrm{km}^{2}$, decreased to 17 million $\mathrm{km}^{2}$ as Russia alone and would decrease to 5 or 4 million $\mathrm{km}^{2}$ following a new wave of dismemberment. Its population also fell from almost 300 million in 1990 (USSR) to 145 million today (Russia), falling from $5.6 \%$ to $1.8 \%$ of the total population world (which between 1990 and 2020 increased from 5.3 to 7.8 billion people). Simulating a possible wave of dismemberment as the Russian economy it is not recovering and the centrifugal forces are more and more present, it would have between 96 
and 110 million people in the future, but taking into account the forecasts of statistical institutions, the already aging population of this country it would continue to decline as the world's population grew. By 2060, Russia without Siberia or the autonomous territories would have no more than 80 million people, while the world's population is set to grow to more than 10.2 billion people, which means it will still have $0,8 \%$ just of the world's population.

Table 1. Comparison between the evolution of the population in Russia and different demographically dynamic states between the years 1950 and 2060.

\begin{tabular}{|c|c|c|c|}
\hline The country & Population in 1950 million inhabitants & 2020 & 2060 estimate \\
\hline Russia (USSR) & 180 & 145 & 133 \\
\hline China & 560 & 1.439 & 1.350 \\
\hline India & 370 & 1.380 & 1.650 \\
\hline Japan & 84 & 126 & 100 \\
\hline Indonesia & 83 & 273 & 340 \\
\hline Brazil & 53 & 212 & 225 \\
\hline Nigeria & 32 & 206 & 475 \\
\hline Mexico & 28 & 129 & 160 \\
\hline Egypt & 21 & 102 & 180 \\
\hline Turkey & 21 & 84 & 100 \\
\hline Iran & 16 & 84 & 105 \\
\hline DR Congo & 13 & 89 & 235 \\
\hline
\end{tabular}

Source: processed after: $[22,14]$.

If at the level of 1950, Russia together with the socialist states united within the USSR had a real demographic concentration for that date, by 2060 it is estimated that its population may be only 110 million people, excluding the declines in following a possible dismemberment. The only measures that will slow down this decline will be to receive tens of millions of immigrants, which will perhaps ensure a slight maintenance or increase of the total population, but with a non-Russian demography closer to the majority and a very Russian population aging. According to Table 1 above, India, which had a double population compared to the USSR in 1950, will be 12 times larger by 2060 , while states with only 10 or $20 \%$ of its population in 1950, it will become two or three times more populated. 7 states: Nigeria, Pakistan, Mexico, Egypt, Turkey, Iran and DR Congo together held as much as the USSR 70 years ago, now being 6 times more populous than the rest of Russia, and in 2060 they will be 12 times over the population of the Russian federation at that time.

Table 2. Russia's economic development and comparison with the economy: USA, EU, Japan, China and India, between 1970 and 2030 forecast (Gross Domestic Product Nominal).

\begin{tabular}{|c|c|c|c|c|c|c|}
\hline Powers & $\begin{array}{l}1970 \text { (Trillion } \\
\text { US dollars) }\end{array}$ & 1980 & 1990 & 2000 & 2019 & Estimate 2030 \\
\hline Russia & 0,400 & 1,200 (U.R.S.S.) & 2,700 (U.R.S.S.) & 0,300 & 1,700 & $2,500-3,000(8,000)$ \\
\hline United States of America & 1,100 & 2,700 & 5,700 & 10,000 & 21,000 & $26,000-33,000$ \\
\hline European Union & 0,600 & 3,000 UE-9 state & $6,400 \mathrm{UE}-12$ & $8,500 \mathrm{UE}-15$ & 19,000 UE-28 & $23,000-30,000$ \\
\hline Japan & 0,200 & 1,000 & 3,000 & 5,000 & 5,000 & $6,000-7,000$ \\
\hline China & 0,090 & 0,180 & 0,400 & 1,200 & 14,000 & $28,000-35,000(55,000)$ \\
\hline India & 0,060 & 0,180 & 0,300 & 0,500 & 3,000 & $7,000-10,000(30,000)$ \\
\hline World & 3,500 & 11,000 & 22,000 & 33,000 & 87,000 & $140,000-170,000(230,000)$ \\
\hline
\end{tabular}

Source: author estimates and data processed by: $[1,12,17,7,16]$.

A slight comparison with the situation of other world economic actors is just as gloomy for Russian power. Until 1990, the power of the USSR was colossal, after which the economic decline went hand in hand with the demographic decline. At the level of 1970, the USSR had an economic power twice that of Japan and 4 and 6 times that of China and India, respectively. At the level of 1970, Russia through the USSR held $11 \%$ of the world's nominal GDP, falling to $10 \%$ in 1980 , rising again to $12 \%$ in 1990 and then declining catastrophically to only $0.9 \%$ in 2000 . Although it is still recovering from a decline of $1.9 \%$ in 2019 , it remains ranked 11th in the world, while the year 2060 brings a lot of uncertainty, with forecasts for Russia ranging from less than 2.5 trillion to more than 8 or 10 trillion US dollars nominal GDP.

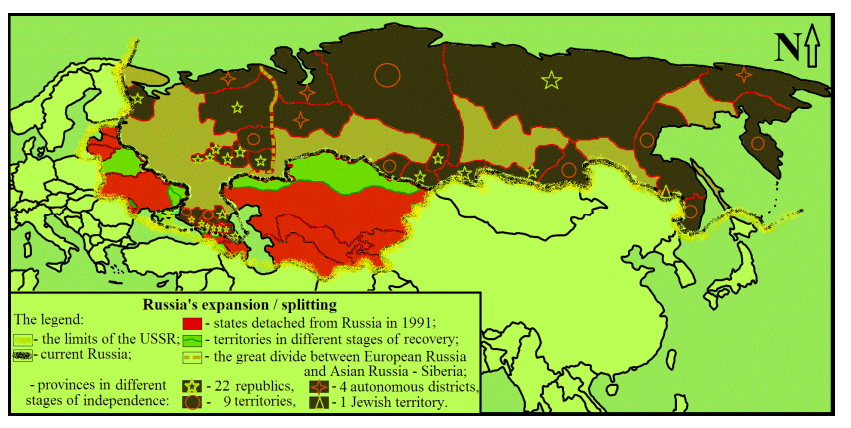

Source: processed after: $[6,2,4,10,15]$.

Figure 1. The USSR, Russia and the territories leaning towards increasing administrative and cultural freedom from Moscow. 
With this decline, Russia is increasingly difficult to hold together, yet there is some cultural and economic chance that would keep Eurasian power in the orbit of the great powers and not be absorbed into an economic union with Europe, East Asia or Central and West Asia, in which she plays a secondary role. This plan is more like a game of chess, which avoids real enemies and attracts imaginary enemies, who no longer have the power to harm this colossus.

\section{The Return Between the Great Powers}

The evil is not impossible to avoid, with Russia still having countless subsoil resources, territories in the process of recovery and states that put their hopes in its aid, while the Russian army, well developed in counterbalance with the economic situation, gives cold shivers even to the superpowers of the USA, China or the European Union.

The national decline of the Russian Federation could be combated with four such strategic measures:

The cultural-economic rapprochement on religious grounds with the Christian-Orthodox states of the Southwest: Ukraine, Romania, Republic of Moldova, Belarus, Greece, Bulgaria, Serbia, Macedonia, Armenia, Georgia, Cyprus, Ethiopia, Kazakhstan and linguistically close the states of the great Slavic language family: Poland, Czech Republic, Slovakia, Belarus, Ukraine, Bulgaria, Serbia, Macedonia, Montenegro, Croatia or Slovenia and the cessation of any retaliation against these peoples, as well as the export of raw materials without coercion and price low, earning their trust and stable economic partner status;

Export of raw materials to two major powers dependent on the Russian market, with a low risk of large territorial grabbing, ie Japan and Germany, allowing these states increased access to the conquered regions from them and schools in their languages, in the Kurile Islands and Sakhalin in Asia for Japan and Kaliningrad in Europe for Germany, avoiding further decline and easing the hatred around it, adding here other overdeveloped states to an economy: "import of raw materials and export of finished products" such as: Italy in Europe and South Korea in Asia (maybe Vietnam, Philippines and India near Japan, Benelux, Switzerland and Austria around Germany). These states are overpopulated, in space crisis and exporters of investment and technology. In order to attract the world perception, it is necessary to attach to Finland, the emblematic state of the Western world that fought against the influence of the USSR, and to allow its cultural-linguistic-economic infiltrations in the province of Karelia;

Military ally outside the states that want territories from it (except: Japan, China, Turkey, Germany or other EU states), such as with a strong strategic state such as India, Iran with its access to the Indian Ocean, and / or even with the USA;

Avoidance / slight cooling of relations with the state of China who wants territories, Turkey influencing the Sunni population of Russia (unlike Iran which has a Shiite Islamist population, which is not strongly represented in Russia) and avoidance of Islamist Central Asian states (except the north
Kazakhstan which is mostly Orthodox);

Receiving immigrants from non-European countries, Islamists or East Asians, immigrants who do not bring geopolitical risks. The ideal areas for receiving immigrants should be: Latin America, South and South-East Asia with the states: India, Nepal, Sri Lanka, the Philippines, Vietnam or Myanmar and the African states: Ethiopia, DRC, Angola or other states from the southern African cone.

A comparison with the situation of other nations, highlights that states rich in resources but with population little dense, they depend substantially on the demographic strength of the neighbors, who are deficient in space and natural wealth. Thus, although Canada has only one neighbor, its population is ten times larger which makes it captive in the forces of US consumers. Neither Libya nor Venezuela do better from this perspective, and Namibia has often faced the greed of its much more populous neighbors, while Australia, although without any territorial neighbors, is close to Indonesia, which is 11 times more populous always feels the pressure of a possible invasion or change in the ethnic structure of the population caused by Asian immigrants. Instead, the US, rich in natural resources, surrounded by neighbors who all make up only half of its population, has always felt safe from this point of view. In the same situation is Brazil, whose neighbors, 10 in number, do not reach the population owned by it, similar to the state of South Africa. Having this comparison of states rich in natural resources, we realize the gravity of the situation regarding Russia. And if we exclude China, the population of all its neighbors, cumulatively, slightly exceeds the country's population. The states of Turkey or Iran, which are close to Russia, hold $80 \%$ of the population of European Russia, a percentage that is constantly growing. On the Asian side, Japan, also close to the territory, has almost $90 \%$ of Russia's population and almost four times more than Asian Russia (Siberia), while China, which has a common border over a distance of $4,300 \mathrm{~km}$, records 10 times more population than the whole of Russia and 40 times more than Siberia (which has slightly larger areas than China). The accumulation of a large number of Islamist inhabitants in southern European Russia and the space crisis of the states of the Far East, force the Russian neighbors to a continuous territorial attraction, making China the most and Turkey in second place, the great greedy for Russian wealth.

Germany and Japan together hold 6 times the nominal gross domestic product of Russia, being states that have developed their economy by importing raw materials and exporting finished products, and together with Italy and South Korea, also states focused on the import of raw materials, the 4 together hold 12 trillion US dollars, 8 times over Russia, states that can not cause major geopolitical problems, these being the key in the current priority of any exporter of raw materials, in finding stable buyers and financial power. Austria, Switzerland and the Benelux countries in Europe are in the same paradigm of large and stable importers of raw materials, and India, Vietnam and the Philippines in Asia will follow in the coming decades. 


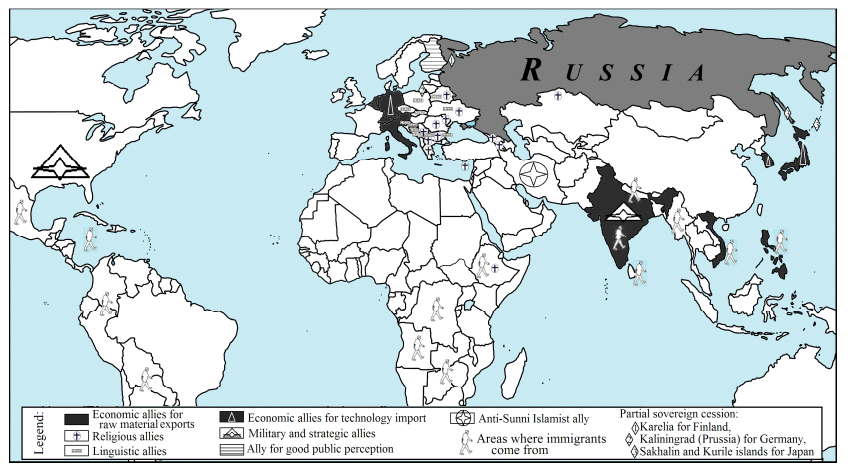

Figure 2. The possible Russian strategy of the 21st century, in combating the national decline.

\section{The Chance of Russia's Huge Resources in Counterbalance with the Hunger for Resources and the Space Crisis of the States Around It}

With the exception of Russia, Europe has an area of only 6 million $\mathrm{km}^{2}$, which is crowded with 600 million people, which means 100 inhabitants $/ \mathrm{km}^{2}$, while in the south-west Southwest Asia (or the Middle East) own 6 million $\mathrm{km}^{2}$ on which there are 300 million inhabitants with 50 inhabitants $/ \mathrm{km}^{2}$ but with a fast growth rate and in the Far East, Russia borders on East Asia which has on its surface of 10 million $\mathrm{km}^{2} 1,6$ billion people with 160 places $\mathrm{km}^{2}$ (over 250 places $/ \mathrm{km}^{2}$ if we exclude the Himalayan Mountains and the Gobi Desert, very little humanized). All this cumulative area of 22 million $\mathrm{km}^{2}$ (excluding sparsely populated Central Asia) with a total of 2,5 billion people, in severe space crisis and in need of resources and agriculture, surrounds the 17 million $\mathrm{km}^{2}$ of Russia populated with only 145 million people and $8 \mathrm{~km}^{2}$. Europe, rich in economics, needs mainly Russian gas and oil, but it also lacks many other basement or wood resources, which are abundant in the Great Russia. Central Asia suffers from a lack of forests and water, being a desert area and projects to divert rivers from Russia through canals to this territory become more viable with population growth and the drying up of Lake Aral (which is an inland sea, rich in fish with only a few decades ago). Southwest Asia suffers from a lack of forests, electricity and agricultural products and is almost devoid of fertile land, while explosive population growth and its concentration in growing cities has increased the need for these materials that Russia wants to export. In contrast, highly humanized and urbanized East Asia, with a rapidly growing degree of industrialization focused on the import of raw materials and the export of finished products, make it vital to import basement, timber and agricultural resources.

The need for wood, water, various subsoil resources and especially agricultural products is growing sharply in the states of the Middle East and the Near East and the development of some of them as well as doubling the population areas in the next 3 decades, will lead to increased imports from Russia. South Asia also, with 1,8 billion people and a growing density of $400 \mathrm{~km}^{2}$, makes it desperate for Russian resources to which they are moving more and more, but the still poor condition of these states nullifies their financial strength for the acquisition of vital resources, but the near future seems to bring prosperity and rapid industrialization, the region becoming the most likely importer of raw materials and exporters of finished products. Passing through the Philippines and Vietnam, which cumulatively reach 200 million people, in situations similar to South or East Asia with a serious need for the import of raw materials and a population density of 300 places $/ \mathrm{km}^{2}$, we reach East Asia, with an increase dynamics of the economy, with rapidly expanding financial strength and on the verge of auction most Russian exports.

Basically, Russia can have some supremacy in the export of raw materials only with the help of Eurasian states, neighboring states direct or close to its borders, with high population densities, expanding financial power and lacking most of the resources they have need. We could consider that this territory is sufficient for the population that occupies it, the export / import balance of materials being close to zero or in excess, in the same advantageous situation being many states on Earth such as: Kazakhstan, Mongolia, Indonesia, Australia, D. R. Congo, South Africa, Brazil, Argentina, Venezuela, USA, Canada, Norway, Sweden or even France. Instead, a number of countries with high population density, rugged or dry land and lack of resources suffer from a need for raw materials that make them prisoners of the states from which they import, most of these countries, with small exceptions in Central America or Africa, finding -especially in Eurasia on the surface of the Rimland: Germany, Holland, Switzerland, Great Britain, Italy, Turkey, Israel, United Arab Emirates, Pakistan, India, Bangladesh, Vietnam, Philippines, China, South Korea or Japan.

If Latin America or Oceania have sufficient resources for their own consumption but also for export, Africa in the midst of a population explosion is still financially weak to bid Russian exports, while the US and Canada have as many resources of their own as they manage to pursue a policy of isolating Russia, thinking of strategies that take it out among the great powers. Throughout this picture, the Rimland surrounding the great Heartland dominated by Russia, is also overcrowded in war, economic competition or fighting over the import of resources being the situation in most states, and they do not allow an isolation or unbalance in any way the giant Russian. Within Rimland there are states focused on the import of raw materials and exports of finished products, with an increasing degree of industrialization, which will make this axis the largest importer of unprocessed products throughout the XXI century, while the Heartland sparsely populated and abundant in the resources needed for Rimland, it is dominated by Russia, remaining a little outside it, in the states of Central Asia, in western China or Eastern Europe. Although there are some tensions between NATO and Russia, however: Italy, Germany, Austria, Greece, Hungary, Turkey, etc. can not cancel their trade with the east, and US 
allies in the Far East such as Japan or South Korea are fighting with bidders Chinese to seize resources exported from Siberia. The states that make up Rimland, with a total of 5 billion people, which means 33 times more population than Russia, will fight hard to form alliances with it, but at the same time, geostrategic risks and external demographic pressure will be colossal and need to be well managed, because what is the privileged position surrounded by the multitude of states waiting on their knees, asking with the money on the table to receive the vital resources of their economies, can also be the reason for Russia's division into dozens of territories easier to grab from the outside.

\section{Conclusions}

The Russian nation has been a superpower of the world for centuries. Ever since she was convinced that it was the 3rd Rome, taking over the role of the Byzantine Empire, this Eurasian power has always continued to surprise with its strength and defense capacity, being among the few states that did not fall completely into the hands of the Mongols, then they came the Western European empires that spread their colonies over most of the planet, but bypassing Russia, and Napoleon failed miserably in his will to conquer it, when killed by blizzards, mud, burned fields and poisonous fountains carefully prepared by The retreating Russians, arrived in Moscow with only $10 \%$ of their army, visiting the city and returning quickly to Paris. Then came the time of Hitler's Germany, which reached the outskirts of Moscow, the city of Vladivostoc (Stalingrad) and surrounded the city of St. Petersburg (Leningrad). Although he organized his entire force to conquer Russia through the Barbarosa project (If he had used the same force to the west, Germany surely he would have conquered in addition to those conquered: France, the Netherlands, Belgium, Denmark and Novegia, she must have penetrated England and his army would have arrived in America), Russia this time, too, it could not be conquered. The countless Japanese attacks of the past centuries have failed, and even after its dismemberment in 1991, the United States has failed to dominate it, making it - the invincibility of the planet. But the growing demographic decline, the demographic and economic growth of the surrounding states and the rebellion of the peoples conquered in the past by the Russians, make this beginning of the XXI century, the darkest scenario and perhaps the first major risk of losing significant areas from Europe and all of Siberia representing Asian Russia. Its enemies are many, economic measures taken and external alliances are most often made to coercion, and diplomacy, knowledge of opponents, strategy and respect for the small states around it are more necessary than ever. China, which is the great economic partner, wants it split, the European Union, which has expanded to its borders, wants it to be part of it, but as a lower-ranking member, the southern Islamist states hope to decimate the Russian Orthodox population replaced by very fertile Muslim populations, and the US or Japan, which could have been allies, wish him harm only for the sake of the unrequited past. As a chess player, calculating the big enemies, the small enemies, the enemies who could become friends and the friends who will be the great enemies of tomorrow, Russia can now tailor another system of military, strategic and economic alliances that would bring it prosperity, nationalism and would maintain its status as a world power.

\section{References}

[1] Ayres, A. (2017). Our time has come: How India is making its place in the World, Oxford University Press.

[2] Barro, A. (2020). A History of Rus: The War in Eastern Ukraine (Essay), La Huerta Grande Publishing House, Madrid.

[3] Bertonha, J. F. (2009). Russia - Rise and Fall of an Empire: A Geopolitical and Military History of Russia, from Tsars to the 21st Century, Juruá Publishing House, Curitaba.

[4] Bulatov, A. S., Kvashnin, Y. D., Mamedova, N. M., Zhdanov, S. V. (2019). The Economy of Russia and Other Post-Soviet Countries, Cambridge Scholars Publishing, Newcastle.

[5] Carvalho, O., Dughin, A. (2016). The United States and the New World Order, Humanitas Publishing House, Bucharest

[6] Duby, G. (2015). Historical atlas, Corint Publishing House, Bucharest.

[7] Findlay, R., O'Rourke, K. (2009). Power and Plenty: trade, war, and the World economy in the second millennium, Princeton University Press, USA.

[8] Friedman, G. (2009). The next 100 years: forecasts for the 21st century, Litera Publishing House, Bucharest.

[9] Graziano, M. (2018). What is the Geopolitics of Religions?, ResetDoc, Milano.

[10] Gray, C. S. (1977). Geopolitics of the Nuclear Era: Heartland, Rimlands, and the Technological Revolution, Crane Russak \& Co.

[11] Grumaz, A. (2013). World War III, Rao Publishing House, Bucharest.

[12] Khanna, P. (2019). The Future is Asian: Global Order in the Twenty-first Century, Weidenfeld \& Nicolson Publishing House, London.

[13] Maçães, B. (2018). The dawn of Eurasia: On the Trail of the New World Order, Penguin Publishing House, Londra, U.K.

[14] Neguţ, S. (2011), Human geography, Academiei Române Publishing House, Bucharest.

[15] O, Brien M. D. (2010), The Island of the World, Ignatius Press.

[16] Pomeranz, K. (2009). The great divergence: China, Europe, and the making of the modern World economy, Princeton University Press.

[17] Reilly, J. (2011). Strong Society, Smart State: The rise of public opinion in China's Japan policy, Contemporary Asia in the World, Columbia University Press, New York.

[18] Romano, S. (2016). Putin and the reconstruction of greater Russia: 1, Longanesi Publishing House, Milano. 
[19] Roy O. (2001). New Central Asia or the Manufacture of Nations, Dacia Publishing House, Cluj-Napoca.

[20] Service, R. (2009). The Penguin History of Modern Russia: From Tsarism to the Twenty-first Century, Editore Penguin, Londra.
[21] The International Institute for Strategic Studies (IISS) (2020), Russia's Military Modernisation: An Assessment, Editora Routledge, Londra.

[22] WORLDOMETERS, real time world statistics: www.worldometers.info, last accessed, November, 2020.

\section{Biography}

Luca Diaconescu is a geopolitical analyst, writing various articles about the geopolitical situation, human and economic geography worldwide. He has a degree of Doctor in Geography obtained at the Universities of Oradea and Craiova, Romania.

Mirela Elena Mazilu teaches especially the geography of tourism at the University of Craiova (Romania), holding the title of Doctoral Professor, publishing articles, books and presentations at conferences about 600 titles. He holds a PhD in Geography from the University of Bucharest, as well as scholarships for excellence and perfection internships at the Universities of Paris and Brussels. 